\title{
Attitude of Students towards Technical Education in Osun State
}

\author{
Dr. B.O. Lawal \\ Department of Teacher Education, Faculty of Education \\ University of Ibadan, Ibadan, Nigeria \\ Tel: 234-803-376-4494Ｅ-mail: Olubodelawwy@yahoo.com
}

Received: July 14, 2011

Accepted: October 9, $2011 \quad$ Published: March 1, 2012

doi:10.5539/ass.v8n3p208

URL: http://dx.doi.org/10.5539/ass.v8n3p208

\begin{abstract}
The study examined the attitude of students towards technical education in Osun State, Nigeria. Descriptive research method was adopted by the investigator. The population of the study was made of 350 students comprising 200 males and 150 females. One validated research instrument was used to gather data. One research hypothesis was answered in the study. The results showed that: male students were more favourably disposed towards Technical Education since there was a significant difference between their mean attitude scores(4.008); students from rural setting had a higher disposition toward Technical Education as compared with their counter parts from the urban setting(4.912); the composition of the students showed a positive disposition with no much difference between their mean attitude scores; the t-value computed to establish the relationship between attitude and performance levels of students showed a negative correlation $(t=-1.48)$; in spite of geographical location there was no marked difference in the attitude and interest of students for Technical Education. Almost half of the colleges do not have enough competent instructors. Among others, it was recommended that the state government should make efforts to purchase more teaching and learning aids for effective teaching in technical colleges. Comprehensive in-service programme must be devised by government for practicing instructors to update their knowledge in their various area of specialization.
\end{abstract}

Keywords: Technical education, Attitude, Secondary schools, Rural and urban schools

\section{Introduction}

Vocational education is synonymous to Technical Education. Vocational education is a highly useful education because its occupational contents offer the trainees the opportunity to acquire skills, attitudes, interest and knowledge that are needed to perform socially and economically, beneficial work, not only to the recipients, but also the society. People who are adequately trained are able to enter into paid employments in any recognized occupation. Consequently, they are able to develop themselves socially and economically as well as contribute to the development of their society. Vocational education is not a new concept in Nigeria education. In the traditional system in Nigeria, children learn by doing. That is to say, children are involved in practical farming, fishing, weaving, cooking, carving, knitting, painting and so on. Technical education in the ordinary sense involves the training of people for lower level jobs such as: Carpentry, Bricklaying, Plumbing, Painting, Ceramics, Textiles, Cabinets-making, Food Technology, Motor mechanics, Installation mechanics, Welding, Baskets-making, Computer, Hair-dressing, Leather work, Blacksmithing and so on.

The belief that Technical Education is for low intelligent students and drop outs from the formal school system is certainly not true. A belief of this nature merely views Vocational Education from a parochial perspective. A careful review of vocational programmes in higher institutions of learning gives a convincing proof that Technical Education demands a lot of mental rigours leading to the acquisition of cognitive, effective and psychomotor elements of behaviour required of a competent worker.

The development of Technical Education in Osun State is dated back to the Old Western State when four colleges were established in 1959 under the auspices of UNESCO. The Fourth National Development plan made it known that between 1980-85, Oyo State government would establishment 18 new Technical Colleges and the existing six technical colleges including the one at Ile-ife would be expanded. At the secondary level, Oyo State would also promote Technical Education by injecting technical subjects into the curriculum of 700 secondary schools and that the Ibadan Polytechnic would be expand with four Satellite campuses at Saki, Esa Oke, Eruwa and Iree which would also make a provision for Business and Technical Education for teachers at N.C.E. level. 
All these were however, carried out except the 18 Technical Colleges which could not be established probably as a result of change of government within the same period. After the creation of Osun State out of the formal Oyo State in 1991, Government Technical College at Osogbo and Ile-Ife and the Ibadan Polytechnic two Satellite Campuses at Esa-oke and Iree fall within Osun State. Recognising the importance of Technical Education as the basis of our technological development and in pursuance of self-employment policy of the government, the Chief Akande led administration in Osun State in 2001 established new seven Technical Colleges across, the state with each having a trade and basic subjects. They are the following: Government Technical College, Inisha which specializes in Ceramics trade, Government Technical College, Gbongan which specializes in Textile trade, Government Technical College at Iwo, specializes on Block laying and Concrete, Government Technical College at Ara specializes in Food Technology, Government Technical College at Osu is for Computer, Government Technical College at Otan-Ayegbaju specializes on Electrical and Electronics while the Government Technical College at Ijebu-jesa specializes on Mechanical aspect.

\section{Related Literature}

\subsection{Technical Education-What People say about It}

According to Adesina (1982), there had been a general misconception of the nature and purpose of Technical Education in developing countries as a whole. He noticed that Craft institutions and Trade centres have often been mis-classified as technical institutions and misconstrued as institutions for the disillusioned primary school leavers or rejects and drop-outs from the secondary grammar schools. For this reason, the institutions were down-graded and made unpopular in the same way that societies in the developing countries regard their products. On the other hand, Vocational Education can be described as a kind of education deliberately designed for the development of skills and knowledge which can be useful to both the individual concerned and the society. Vocational Education can also be described as a kind of educational programme geared towards imparting knowledge and for a better living. According to Oni (1994) he is of the opinion that Technical Education is given to those who need to be employed in commerce and industry or in any time of enterprise which involves the use of tools and other machinery for their operational service. Babarinde (Ed 2000) is of a better opinion by saying that the first obligation of an education system is to produce citizen with employable skills that could help them secure and keep employment. While contributing to the development of Technical Education, Lawal (1987) noted that this kind of education developed very slowly in Nigeria. According to him, it is of recent that better attention is being given to technical education in Nigeria.

Vocational Education has been described as one's occupation, or work, or one's means of livelihood. Commenting on the vocational and technical aspects of the secondary school education Olaitan (1996) among others applauded the inclusion of introductory technology curriculum, practical agriculture and Home Economics as a result of the realization of Technical Education as a veritable instrument of social-economic and political development.

\subsection{Development of Technical Education in Nigeria}

The major problem facing the development of Technical Education in Nigeria and in Osun State in particular could not be divorced from low priority accorded to Technical and Vocational Education. Many researches have been carried out by many educators in Nigeria. Fafunwa (1974) observed that the 1945 recommendation on Technical and Vocational Education was supported by the 1946 ten - year plan for development and welfare when it proposed Handicraft centres for training in manual arts, Trade centres for the training of skilled craftsmen, and Technical institutes for the training of technicians. It was as a result of this that the government under the colonial development and welfare scheme provided a grant of $\$ 400,000(\$ 800,000)$ for the promotion of Technical and Vocational Education for the first five years. In comparing the traditional form of education with the present day Technical Education, Awoniyi (1979) observed that in traditional societies, there is no unemployment especially where some form of Vocational Education was being taught to the children which could make an individual a useful member of his society.

Omolewa (1981) in his study on adult education practice in Nigeria, confirmed that some form of Vocational Education was going on in the traditional society before the introduction of formalized Technical and Vocational Education by the Christian missions. For instance, a father who was versed in medicine or drumming, tailoring or barbing would encourage his children to adopt his profession. Contributing to the development of Technical Education in Nigeria, Taiwo (1985) observed that some progress was made in the 1960s in the production of technicians and artisans but it was short of the needs of the country. According to him some of the difficulties were shortage of Vocational and Technical Institutions arising from the high cost of outlay and running expenses 
and the lack of qualified instructors and lecturers of technical subjects as well as lack of appreciation by the public of technicians and artisans.

In his own contribution to the debate on the development of Technical Education in Nigeria, Osokoya (1985) observed that the absence of pre-vocational studies have given Nigerian Education Policy makers great concern over the ages and that over a century, policy formulators in Nigeria have grappled with the provision of pre-Vocational Education for the youth but lost the battle each time. Supporting others' claim on the missionaries contribution to Technical Education in Nigeria, he believed that the missionaries who brought formal education to Nigeria had at the back of their mind a philosophy of education for the Nigerians which they called - "The Bible and the plough".

\section{Methodology}

\subsection{Research Design}

The study adopted descriptive research method. The reason was that descriptive research method was found to be appropriate for the study.

\subsection{Population and sample}

The population for the study consisted of the students in the Technical Colleges in Osun State. The sample respondents are 350 in number which were randomly selected from all the Technical Colleges in the state. It was made up of 200 males and 150 females.

\subsection{Instruments}

For the purpose of this study Likert-type questionnaire was used, coupled with personal interview. The response was rated on five column Likert attitude scale, strongly agree, Agree, Undecided, Disagree, Strongly disagree. The respondents will be required to tick appropriate column. The questionnaire consisted of the following information.
a. Name of the School
b. Sex of Student
c. Age of Student
d. Class
e. Number of Students in their class

The second section dealt with instruction on how to fill the questionnaire, and elicited responses from the students concerning their attitude towards Technical Education. The questionnaire covered mainly the following areas:

(1). Importance of Technical Education

(2). Inner motivational variable

(3). Outer motivational variable

\subsection{Hypothesis}

There is no significant difference between the mean attitude scores of male and female students.

\subsection{Data analysis}

Data were analysed using descriptive statistics of Mean, frequency counts and $t$ - test. The questionnaire was analysed by assigning scale values to responses. For positively structured items, the value will be assigned as follows, strongly agree 5 , agree 4 , undecided 3 , disagree 2 , strongly disagree 1 . For negatively structured items, the values will be assigned in a reverse order thus: Strongly agree 1, agree 2, undecided 3, disagree4, strongly disagree 5 . The $t$-test statistic was used to test hypothesis $1,2,3$ at 0.05 level of significance

\section{Results}

Table 1 shows the overall students attitude in technical schools with the overall mean score, variance, standard deviation, negative attitude which represent 2.4 below and positive attitude is 2.5 and above. The overall mean score of the overall students with 200 technical students sampled is 3.920 or $81.4 \%$. The overall variance is 0.146 while standard deviation is 0.382 . This shows the general view of the students towards technical education in the state. 
Table 2 shows the attitude of female students in technical schools with overall mean score, variance, standard deviation, negative attitude which represent 2.4 below and positive attitude is 2.5 and above. The overall mean score of the attitude of female students with 100 technical school students sampled is 3.912 or $78.3 \%$. The overall variance is 0.198 and the standard deviation is 0.444 . This corroborates the realistic of the general attribute of all students as shown in table one.

Table 3 shows the attitude of male students toward Technical Education with the overall mean score, variance, standard deviation, negative attitude which represent 2.4 below while positive attitude is 2.5 and above. The overall mean score of the attitude of male students with 100 technical students sampled is 4.008 or $80.2 \%$. This shows that male students are more interested in Technical Education than female students. The overall variance is 0.138 while standard deviation is 0.371 . This also is in line with overall students' attitude as revealed in table one.

Table 4 shows the attitude of students in unisex technical school with the overall mean score, variance, standard deviation, negative attitude which represent 2.4 below while positive attitude is 2.5 and above. The overall mean score of the attitude of students in unisex technical school with 80 technical students sampled is 3.850 or $77 \%$. The mean score is slightly different from other result. The overall variance is 0.227 while standard deviation is 0.476. This is an indication that the result in table one is in line

Table 5 shows the attitude of students in Co-educational technical schools with the overall mean score, variance, standard deviation, negative attitude which represent 2.4 below while positive attitude is 2.5 and above. The overall mean score of the attitude of students in Co-educational technical schools with 120 technical students sampled is 3.920 or $78.4 \%$. The mean score is slightly above that of unisex school. The overall variance is 0.196 while standard deviation is 0.443 . The result showed positive attitude, this revealed the presence of healthy competition between male and female students.

Table 6 depict the attitude of Technical Students in Rural technical schools the overall mean, variance, standard deviation, negative attitude which represent 2.4 and below while positive attitude is 2.5 and above. The overall mean score of the attitude of students in Rural technical schools with 80 students sampled is 3.912 or $78.3 \%$ the mean is slightly higher than that of urban area. The overall variance is 0.175 while standard deviation is 0.418 . The result is positive in the sense that it shows that students in rural area seem to be more interested in Technical Education than their counterpart in urban areas.

Table 7 shows the overall attitude of Technical Students in Urban technical schools, the overall mean, variance, standard deviation, negative attitude which represent 2.4 and below while positive attitude is 2.5 and above. The overall mean score of the attitude of students in urban area with 120 technical students sampled is 3.904 or $78.1 \%$ though the mean is slightly lower than that of rural area. The overall variance is 0.159 while standard deviation is 0.399 . The result is valid in that it revealed the positive attitude of the students toward Technical Education. The result depicts that all the students had a high positive attitude toward Technical Education with the mean attitude scores of 3.920 which represent $78.4 \%$. The male students, female students, students both in urban, rural, co-educational and single sex schools all the students showed a very high positive disposition towards Technical Education with their mean attitude scores as 4.008 or $80.2 \%, 3.912$ or $78.3 \%, 3.904$ or $78.1 \%$, 3.912 or $78.3 \%, 3.904$ or $78.1 \%, 3.912$ or $78.3 \%, 3 \%, 3.929$ or $78.6 \%$ and 3.850 or $77 \%$ respectively.

Testing of research hypotheses

There is no significant difference between the mean attitude scores of male and female students.

Table 8 shows the mean attitude scores, standard deviation and t-value 4.008 mean score was recorded in favour of male student against 3.192 for the females which shows slight difference. Since the calculated $t$ [2.02] is greater than the tabulated $t$ [1.96] the hypothesis was rejected. Meaning a statistically significant difference was observed between the mean attitude scores of male and female students towards Technical Education.

As revealed in table 9, there is a slight difference in the mean attitude scores of the response, therefore, the $t$ calculated [0.167] is less than the t-tabulated of [1.96] thus the t-calculated is not significant and the hypothesis was accepted.

From table 10, the t-calculated [0.001] is less than the t. tabulated [0.164] is not significant. This shows a negative relationship between the students' attitude and their performance in technical schools.

The mean score from table 11 shows that mixed schools have higher scores of 3.929 as against 3.850 for the unisex. Consequently the $\mathrm{t}$ - calculated $[-1.48]$ is significant because it is more them the $t$. tabulated [-1.96] thus the hypothesis was rejected. 
From the result presented below, it was revealed that:

(1). Male students were more favourably disposed towards Technical Education since there was a significant difference between their mean attitude scores table 1 show this.

(2). The results shown in table 2 revealed that students from rural setting had a higher disposition toward Technical Education as compared with their counter parts from the urban setting.

(3). The composition of the students showed a positive disposition with no much difference between their mean attitude scores.

(4). The t-value computed to establish the relationship between attitude and performance levels of students showed a negative correlation.

In conclusion, it was revealed that inspite of geographical location; there was no marked difference in the attitude and interest of students for Technical Education

\section{Discussion}

Students' attitude towards Technical education

In the study, it was discovered that most students had very high positive attitudes toward Technical Education with mean attitude score of 3.920 as an overall student attitude. They demonstrated a positive attitude to almost all the items in the questionnaire. From these responses to the items in the questionnaire it appeared that most students felt that some technical aspect and areas are difficult, they also agreed that practical aspects are strenuous, difficult and expensive for them. It is also gathered that most of the technical instructors are not competent in handling various aspects of the course. Item 19 in the questionnaire confirm the statement. Some of the students agreed that they are into Technical Education because they like practical oriented profession. This is shown from their response to item 8,9,15 and 16 in the questionnaire. Majority are into Technical Education because of their desire for self sustainable future career. This is revealed in their response to item 15 . Aside from the above, other findings on students' attitude to Technical Education include: It was found that both male and female students showed positive disposition towards the programme with mean attitude scores of 4.008 and 3.912 respectively. Going through the table, it is shown that both male and female have a positive attitude toward the program. The fact that male have higher mean score of 4.008 while female have 3.912 may be attributed to the fact that male students seem to have inclination toward practical oriented courses of which Technical Education program is known for. In addition, other findings in the study shows that the attitude of students in rural areas (that is outside the state capital) was no significantly different from those in urban centre. But a close look at the means revealed that students in rural colleges showed more positive disposition.

The relationship between attitude of the students and their performance in Technical Education

The findings revealed that there were no positive relationships between attitude of the students and their performance. This is evident from the attitudes mean scores of 3.92 which represented $78.4 \%$ while the performance mean scores stand at 47.3 which also represents $47.3 \%$. The negative relationship may be traced to the findings that most of the colleges do not have enough competent instructors and students are poorly motivated though most of the students were very much interested in the course. This was confirmed through interview and personal interaction and observation. It was also revealed that, students in urban centre performed fairly better than their counterparts outside the state capital colleges. The difference in their mean percentage shows that $49.2 \%$ for the urban colleges while $44.3 \%$ is for the rural colleges. This may be due to the fact that students in urban are more exposed to more opportunities to learning or availability of more qualified instructors, learning materials coupled with possible medium and higher socio-economic status. All of which may not be found outside the state capital.

\section{Conclusion}

The result of this study which has tried to determine the students' attitude toward Technical Education leads to the following conclusion

(1) Most of the students in the sampled colleges showed a positive disposition towards Technical Education.

(2) The attitude of students to Technical Education was found not to relate to their performance in their various courses

(3) Almost half of the colleges do not have enough competent instructors, because of the inability of the government to place Technical Education in the right priority. Also it was revealed that some of the instructors were not well trained. Many of them possessed S.75, school certificate drop-out, ND, etc. 


\section{Recommendations}

In order to ensure secured future for the students and to achieve the aim and objective of Technical Education, the following recommendations are necessary:

(1). State government should intensify efforts to procure more teaching and learning aids for effective acquisition of desirable skill.

(2). There is an urgent need for more qualified technical instructors to enhance the achievement of the goals of Technical Education.

(3). Comprehensive in-service program must be devised by government for practicing instructors to update their knowledge in their various area of specialization. And the students should be given elaborate instruction and information about the future opportunity that open before them and not to see themselves as unfortunate.

\section{References}

Adesina, S. (1982). Planning and Educational Development in Nigeria. Board Publications Limited.

Awoniyi T.A. (1979). Principles and Practice of Education Holders and Stoughton. London, Sydney, Auckland and Toronto.

Babarinde, K (Ed). (2000). Educational and the Challenge of Patriotism in Nigeria. Abeokuta: Philosophy of Education Association of Nigeria (PEAN).

Fafunwa, A.B. (1974). History of Education in Nigeria. London George Allen and Unwin Ltd.

Federal Republic of Nigeria. (1998). National Policy on Education. Lagos, Federal Ministry of Education.

Lawal, B.O. (1987). Trends in the Development of Technical Education in Oyo State 1977-87. (M.Ed Thesis) University of Ibadan.

Olaitan, S.O. (1996). Vocational and Technical Education in Nigeria: Issues and Analysis. Onitsha Noble graphics Press Publishers.

Omolewa, M. (1981). Adult Education Practice in Nigeria. Evans Brother (Nigeria Publishers) Limited.

Oni, B. (1998). Personnel and Finance as Factors in Middle level Technical Education Development in Oyo State, 1979-1984. (Ph.D. Thesis) University of Ibadan, 1985 National Policy on Education.

Osokoya I.O. (1995). The Prospects and Problems of Implementation the Secondary components of the National Policy on Education. (Ph.D Thesis) University of Ibadan.

Taiwo C.O. (1985). The Nigerian Education System, Past, Present and Future. Nigeria, Nelson Pitman Ltd. 
Table 1. Overall Stuents' Attitude (200)

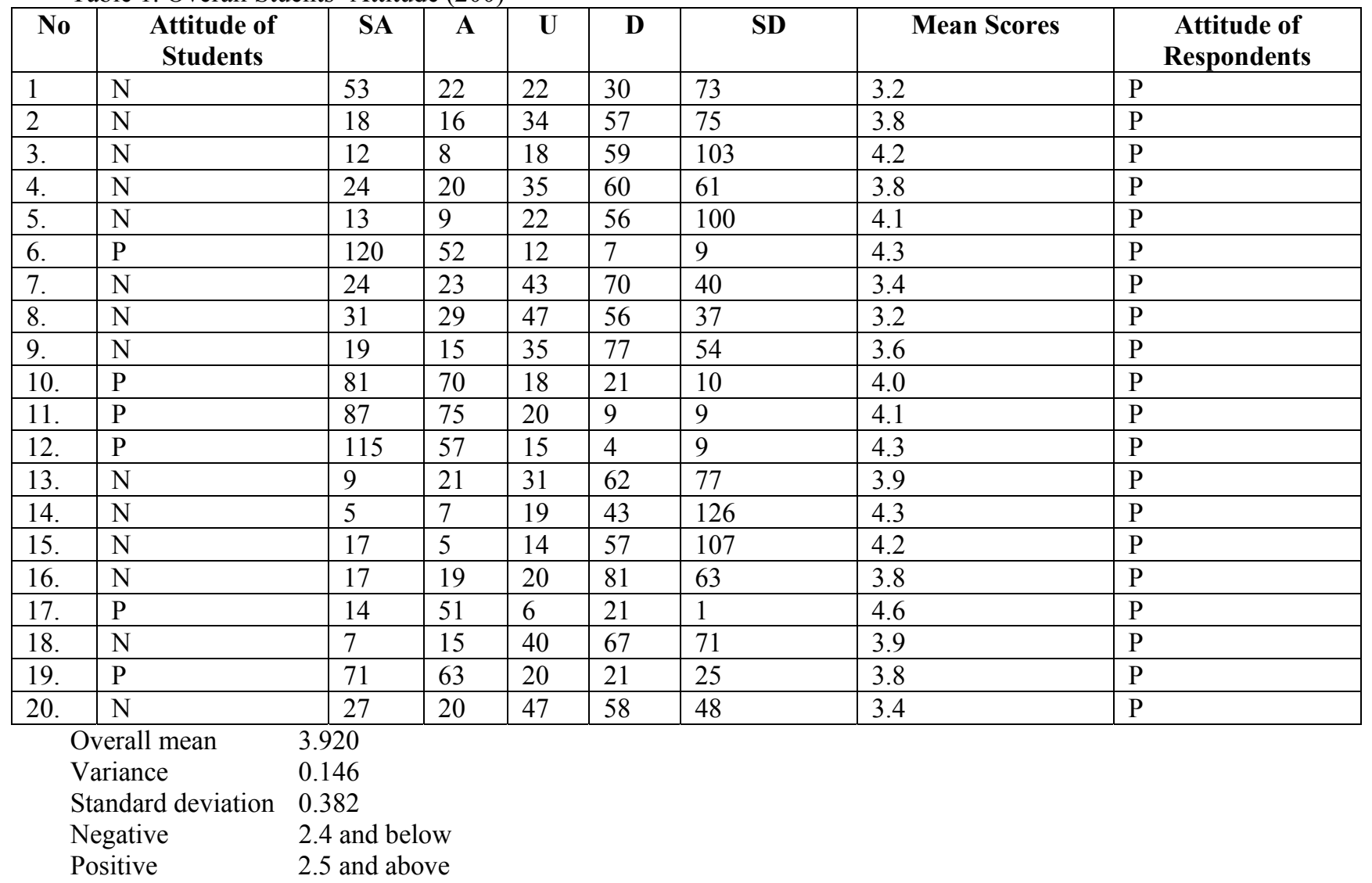

Table 2. Attitude of Female Students (100)

\begin{tabular}{|c|c|c|c|c|c|c|c|c|c|}
\hline No & \multicolumn{2}{|c|}{$\begin{array}{l}\text { Attitude of } \\
\text { Students }\end{array}$} & SA & $\mathbf{A}$ & $\mathbf{U}$ & D & SD & $\begin{array}{l}\text { Mean } \\
\text { Scores }\end{array}$ & $\begin{array}{c}\text { Attitude of } \\
\text { Respondents }\end{array}$ \\
\hline 1 & \multicolumn{2}{|c|}{$\mathrm{N}$} & 26 & 10 & 10 & 22 & 33 & 3.2 & $P$ \\
\hline 2 & \multicolumn{2}{|l|}{$\mathrm{N}$} & 9 & 8 & 18 & 25 & 40 & 3.8 & $P$ \\
\hline 3. & \multicolumn{2}{|l|}{$\mathrm{N}$} & 4 & 3 & 7 & 32 & 54 & 4.3 & $P$ \\
\hline 4. & \multicolumn{2}{|l|}{$\mathrm{N}$} & 11 & 9 & 19 & 27 & 34 & 3.6 & $P$ \\
\hline 5. & \multicolumn{2}{|l|}{$\mathrm{N}$} & 5 & 2 & 15 & 26 & 52 & 4.2 & $P$ \\
\hline 6. & \multicolumn{2}{|l|}{$\mathrm{P}$} & 63 & 22 & 8 & 3 & 4 & 4.8 & $\mathrm{P}$ \\
\hline 7. & \multicolumn{2}{|l|}{$\mathrm{N}$} & 17 & 9 & 16 & 39 & 19 & 3.3 & $\mathrm{P}$ \\
\hline 8. & \multicolumn{2}{|l|}{$\mathrm{N}$} & 18 & 8 & 19 & 33 & 22 & 3.3 & $\mathrm{P}$ \\
\hline 9. & \multicolumn{2}{|l|}{$\mathrm{N}$} & 9 & 3 & 16 & 42 & 30 & 3.8 & $\mathrm{P}$ \\
\hline 10. & \multicolumn{2}{|l|}{$\mathrm{P}$} & 46 & 31 & 8 & 10 & 5 & 4.0 & $\mathrm{P}$ \\
\hline 11. & \multicolumn{2}{|l|}{$\mathrm{P}$} & 45 & 33 & 15 & 2 & 5 & 4.1 & $P$ \\
\hline 12. & \multicolumn{2}{|l|}{$\mathrm{P}$} & 59 & 30 & 9 & 2 & - & 4.5 & $P$ \\
\hline 13. & \multicolumn{2}{|l|}{$\mathrm{N}$} & 10 & 6 & 19 & 25 & 40 & 3.8 & $P$ \\
\hline 14. & \multicolumn{2}{|l|}{$\mathrm{N}$} & 5 & 5 & 11 & 19 & 60 & 4.1 & $P$ \\
\hline 15. & \multicolumn{2}{|l|}{$\mathrm{N}$} & 10 & 2 & 8 & 23 & 57 & 4.2 & $\mathrm{P}$ \\
\hline 16. & \multicolumn{2}{|l|}{$\mathrm{N}$} & 9 & 10 & 10 & 44 & 27 & 3.7 & $P$ \\
\hline 17. & \multicolumn{2}{|l|}{$P$} & 63 & 29 & 6 & 1 & 1 & 4.5 & $P$ \\
\hline 18. & \multicolumn{2}{|l|}{$\mathrm{N}$} & 5 & 6 & 21 & 33 & 35 & 3.9 & $\mathrm{P}$ \\
\hline 19. & \multicolumn{2}{|l|}{$\mathrm{P}$} & 31 & 32 & 5 & 15 & 17 & 3.5 & $P$ \\
\hline 20. & \multicolumn{2}{|l|}{$\mathrm{N}$} & 15 & 13 & 20 & 33 & 19 & 3.3 & $\mathrm{P}$ \\
\hline \multicolumn{10}{|c|}{ Overall mean 3.912} \\
\hline \multicolumn{2}{|c|}{ Variance } & 0.198 & & & & & & & \\
\hline \multicolumn{2}{|c|}{ Standard deviation } & 0.444 & & & & & & & \\
\hline \multicolumn{2}{|c|}{ Negative } & 2.4 an & elow & & & & & & \\
\hline \multicolumn{2}{|c|}{ Positive } & 2.5 an & bove & & & & & & \\
\hline
\end{tabular}


Table 3. Attitude of Male Students

\begin{tabular}{|c|c|c|c|c|c|c|c|c|c|}
\hline No & \multicolumn{2}{|c|}{ Attitude of Students } & $\mathbf{S A}$ & $\mathbf{A}$ & $\mathbf{U}$ & D & SD & $\begin{array}{l}\text { Mean } \\
\text { Scores }\end{array}$ & $\begin{array}{c}\text { Attitude of } \\
\text { Respondents }\end{array}$ \\
\hline 1 & \multicolumn{2}{|l|}{$\mathrm{N}$} & 22 & 11 & 11 & 14 & 42 & 3.4 & $P$ \\
\hline 2 & \multicolumn{2}{|l|}{$\mathrm{N}$} & 5 & 7 & 19 & 32 & 37 & 3.9 & $\mathrm{P}$ \\
\hline 3. & \multicolumn{2}{|l|}{$\mathrm{N}$} & 5 & 4 & 9 & 31 & 51 & 4.2 & $\mathrm{P}$ \\
\hline 4. & \multicolumn{2}{|l|}{$\mathrm{N}$} & 8 & 8 & 14 & 35 & 35 & 3.8 & $P$ \\
\hline 5. & \multicolumn{2}{|l|}{$\mathrm{N}$} & 6 & 4 & 6 & 28 & 56 & 4.2 & $\mathrm{P}$ \\
\hline 6. & \multicolumn{2}{|l|}{$P$} & 53 & 31 & 8 & 3 & 5 & 4.2 & $P$ \\
\hline 7. & \multicolumn{2}{|l|}{$\mathrm{N}$} & 4 & 10 & 29 & 33 & 24 & 3.6 & $\mathrm{P}$ \\
\hline 8. & \multicolumn{2}{|l|}{$\mathrm{N}$} & 13 & 19 & 28 & 23 & 17 & 3.1 & $P$ \\
\hline 9. & \multicolumn{2}{|l|}{$\mathrm{N}$} & 5 & 7 & 20 & 41 & 27 & 3.8 & $P$ \\
\hline 10. & \multicolumn{2}{|l|}{$\mathrm{P}$} & 38 & 39 & 10 & 9 & 4 & 4.0 & $P$ \\
\hline 11. & \multicolumn{2}{|l|}{$\mathrm{P}$} & 42 & 39 & 9 & 7 & 3 & 4.1 & $P$ \\
\hline 12. & \multicolumn{2}{|l|}{$\mathrm{P}$} & 61 & 27 & 7 & 2 & 3 & 4.4 & $P$ \\
\hline 13. & \multicolumn{2}{|l|}{$\mathrm{N}$} & - & 13 & 10 & 39 & 39 & 3.9 & $\mathrm{P}$ \\
\hline 14. & \multicolumn{2}{|l|}{$\mathrm{N}$} & 1 & 1 & 10 & 21 & 67 & 4.5 & $P$ \\
\hline 15. & \multicolumn{2}{|l|}{$\mathrm{N}$} & 5 & 1 & 5 & 35 & 54 & 4.3 & $\mathrm{P}$ \\
\hline 16. & \multicolumn{2}{|l|}{$\mathrm{N}$} & 5 & 6 & 11 & 43 & 35 & 4.0 & $\mathrm{P}$ \\
\hline 17. & \multicolumn{2}{|l|}{$\mathrm{P}$} & 76 & 20 & 2 & 2 & - & 4.7 & $P$ \\
\hline 18. & \multicolumn{2}{|l|}{$\mathrm{N}$} & - & 6 & 20 & 36 & 38 & 4.0 & $P$ \\
\hline 19. & \multicolumn{2}{|l|}{$P$} & 41 & 26 & 13 & 8 & 12 & 3.8 & $\mathrm{P}$ \\
\hline 20. & \multicolumn{2}{|l|}{$\mathrm{N}$} & 9 & 8 & 28 & 27 & 28 & 3.6 & $\mathrm{P}$ \\
\hline \multicolumn{10}{|c|}{$\begin{array}{ll}\text { Overall mean } & 4.008\end{array}$} \\
\hline \multicolumn{2}{|c|}{$\begin{array}{l}\text { Variance } \\
\text { Standard deviation }\end{array}$} & 0.138 & & & & & & & \\
\hline \multirow{2}{*}{\multicolumn{2}{|c|}{ Standard deviation }} & 0.371 & & & & & & & \\
\hline & & 2.4 and below & & & & & & & \\
\hline \multicolumn{2}{|c|}{$\begin{array}{l}\text { Negative } \\
\text { Positive }\end{array}$} & 5 and & & & & & & & \\
\hline
\end{tabular}

Table 4. Attitude of Students in Unisex School (80)

\begin{tabular}{|c|c|c|c|c|c|c|c|c|c|}
\hline No & $\begin{array}{r}\text { Attitu } \\
\text { Stud }\end{array}$ & $\begin{array}{l}\text { de of } \\
\text { ents }\end{array}$ & SA & $\mathbf{A}$ & $\mathbf{U}$ & D & SD & $\begin{array}{l}\text { Mean } \\
\text { Scores }\end{array}$ & $\begin{array}{c}\text { Attitude of } \\
\text { Respondents }\end{array}$ \\
\hline 1 & $\mathrm{~N}$ & & 13 & 12 & 4 & 18 & 33 & 3.6 & $P$ \\
\hline 2 & $\mathrm{~N}$ & & 7 & 5 & 14 & 23 & 31 & 3.8 & $\mathrm{P}$ \\
\hline 3. & $\mathrm{~N}$ & & 1 & 2 & 7 & 27 & 43 & 4.4 & $P$ \\
\hline 4. & $\mathrm{~N}$ & & 5 & 7 & 15 & 29 & 24 & 3.6 & $\mathrm{P}$ \\
\hline 5. & $\mathrm{~N}$ & & 3 & 6 & 4 & 23 & 44 & 4.2 & $\mathrm{P}$ \\
\hline 6. & $\mathrm{P}$ & & 35 & 31 & 5 & 4 & 5 & 4.1 & $\mathrm{P}$ \\
\hline 7. & $\mathrm{~N}$ & & 11 & 8 & 16 & 33 & 12 & 3.3 & $\mathrm{P}$ \\
\hline 8. & $\mathrm{~N}$ & & 9 & 11 & 22 & 23 & 15 & 2.5 & $\mathrm{P}$ \\
\hline 9. & $\mathrm{~N}$ & & 7 & 2 & 11 & 42 & 13 & 3.8 & $\mathrm{P}$ \\
\hline 10. & $\mathrm{P}$ & & 24 & 32 & 9 & 10 & 5 & 3.8 & $\mathrm{P}$ \\
\hline 11. & $\mathrm{P}$ & & 25 & 32 & 13 & 4 & 6 & 3.8 & $\mathrm{P}$ \\
\hline 12. & $\mathrm{P}$ & & 43 & 24 & 7 & 4 & 2 & 4.3 & $P$ \\
\hline 13. & $\mathrm{~N}$ & & 6 & 9 & 10 & 28 & 27 & 3.8 & $P$ \\
\hline 14. & $\mathrm{~N}$ & & 3 & 5 & 5 & 16 & 51 & 4.3 & $\mathrm{P}$ \\
\hline 15. & $\mathrm{~N}$ & & 2 & 1 & 3 & 24 & 50 & 4.5 & $\mathrm{P}$ \\
\hline 16. & $\mathrm{~N}$ & & 8 & 5 & 7 & 41 & 19 & 3.7 & $\mathrm{P}$ \\
\hline 17. & $\mathrm{P}$ & & 53 & 24 & 1 & 1 & 1 & 4.6 & $\mathrm{P}$ \\
\hline 18. & $\mathrm{~N}$ & & 2 & 7 & 11 & 35 & 25 & 3.9 & $\mathrm{P}$ \\
\hline 19. & $\mathrm{P}$ & & 24 & 22 & 6 & 12 & 16 & 3.3 & $\mathrm{P}$ \\
\hline 20. & $\mathrm{~N}$ & & 11 & 5 & 23 & 26 & 15 & 3.4 & $\mathrm{P}$ \\
\hline \multicolumn{10}{|c|}{ Overall mean } \\
\hline \multicolumn{2}{|c|}{ Variance } & 0.227 & & & & & & & \\
\hline \multicolumn{2}{|c|}{ Standard deviation } & 0.476 & & & & & & & \\
\hline \multicolumn{2}{|c|}{ Negative } & 2.4 an & elow & & & & & & \\
\hline \multicolumn{2}{|c|}{ Positive } & 2.5 an & bove & & & & & & \\
\hline
\end{tabular}


Table 5. Attitude of Students in Co-Educational School (120)

\begin{tabular}{|c|c|c|c|c|c|c|c|c|c|}
\hline No & \multicolumn{2}{|c|}{$\begin{array}{l}\text { Attitude of } \\
\text { Students }\end{array}$} & SA & $\mathbf{A}$ & $\mathbf{U}$ & D & SD & $\begin{array}{l}\text { Mean } \\
\text { Scores }\end{array}$ & $\begin{array}{c}\text { Attitude of } \\
\text { Respondents }\end{array}$ \\
\hline 1 & \multicolumn{2}{|l|}{$\mathrm{N}$} & 40 & 10 & 20 & 12 & 40 & 3.1 & $P$ \\
\hline 2 & \multicolumn{2}{|l|}{$\mathrm{N}$} & 11 & 11 & 14 & 34 & 41 & 3.6 & $\mathrm{P}$ \\
\hline 3. & \multicolumn{2}{|l|}{$\mathrm{N}$} & 11 & 6 & 17 & 35 & 53 & 4.0 & $P$ \\
\hline 4. & \multicolumn{2}{|l|}{$\mathrm{N}$} & 19 & 13 & 20 & 31 & 37 & 3.6 & $P$ \\
\hline 5. & \multicolumn{2}{|l|}{$\mathrm{N}$} & 10 & 3 & 18 & 33 & 56 & 4.0 & $P$ \\
\hline 6. & \multicolumn{2}{|l|}{$\mathrm{P}$} & 85 & 21 & 7 & 3 & 4 & 4.5 & $P$ \\
\hline 7. & \multicolumn{2}{|l|}{$\mathrm{N}$} & 13 & 15 & 27 & 37 & 28 & 3.4 & $P$ \\
\hline 8. & \multicolumn{2}{|l|}{$\mathrm{N}$} & 12 & 13 & 24 & 35 & 36 & 3.5 & $\mathrm{P}$ \\
\hline 9. & \multicolumn{2}{|l|}{$\mathrm{N}$} & 57 & 38 & 9 & 11 & 5 & 4.1 & $P$ \\
\hline 10. & \multicolumn{2}{|l|}{$\mathrm{P}$} & 62 & 43 & 7 & 5 & 5 & 4.3 & $P$ \\
\hline 11. & \multicolumn{2}{|l|}{$\mathrm{P}$} & 22 & 18 & 25 & 33 & 22 & 3.1 & $\mathrm{P}$ \\
\hline 12. & \multicolumn{2}{|l|}{$\mathrm{P}$} & 72 & 33 & 8 & - & 7 & 4.4 & $P$ \\
\hline 13. & \multicolumn{2}{|l|}{$\mathrm{N}$} & 3 & 12 & 21 & 34 & 50 & 4.0 & $\mathrm{P}$ \\
\hline 14. & \multicolumn{2}{|l|}{$\mathrm{N}$} & 2 & 2 & 14 & 27 & 75 & 4.4 & $P$ \\
\hline 15. & \multicolumn{2}{|l|}{$\mathrm{N}$} & 15 & 4 & 11 & 33 & 57 & 4.0 & $P$ \\
\hline 16. & \multicolumn{2}{|l|}{$\mathrm{N}$} & 9 & 14 & 13 & 40 & 44 & 3.8 & $\mathrm{P}$ \\
\hline 17. & \multicolumn{2}{|l|}{$\mathrm{P}$} & 87 & 27 & 5 & 1 & - & 4.7 & $\mathrm{P}$ \\
\hline 18. & \multicolumn{2}{|l|}{$\mathrm{N}$} & 5 & 8 & 29 & 32 & 46 & 3.9 & $P$ \\
\hline 19. & \multirow{2}{*}{\multicolumn{2}{|c|}{$\frac{P}{N}$}} & 47 & 41 & 14 & 9 & 11 & 3.9 & $\mathrm{P}$ \\
\hline 20. & & $\mathrm{~N}$ & 16 & 15 & 24 & 32 & 33 & 3.4 & $\mathrm{P}$ \\
\hline \multicolumn{10}{|c|}{ Overall mean $\quad 3.920$} \\
\hline \multirow{2}{*}{\multicolumn{2}{|c|}{$\begin{array}{l}\text { Variance } \\
\text { Standard deviation }\end{array}$}} & 0.196 & & & & & & & \\
\hline & & 0.443 & & & & & & & \\
\hline \multicolumn{2}{|c|}{ Negative } & $2.4 \mathrm{ar}$ & low & & & & & & \\
\hline \multicolumn{2}{|c|}{ Positive } & & ove & & & & & & \\
\hline
\end{tabular}

Table 6. Attitude of Students in Rural School (80)

\begin{tabular}{|c|c|c|c|c|c|c|c|c|c|}
\hline No & $\begin{array}{r}\text { Attitu } \\
\text { Stud }\end{array}$ & $\begin{array}{l}\text { de of } \\
\text { ents }\end{array}$ & SA & $\mathbf{A}$ & $\mathbf{U}$ & D & SD & $\begin{array}{l}\text { Mean } \\
\text { Scores }\end{array}$ & $\begin{array}{c}\text { Attitude of } \\
\text { Respondents }\end{array}$ \\
\hline 1 & $\mathrm{~N}$ & & 4 & 5 & 15 & 7 & 29 & 3.2 & $\bar{P}$ \\
\hline 2 & $\mathrm{~N}$ & & 6 & 7 & 15 & 23 & 29 & 3.8 & $P$ \\
\hline 3. & $\mathrm{~N}$ & & 7 & 5 & 6 & 25 & 27 & 4.0 & $P$ \\
\hline 4. & $\mathrm{~N}$ & & 13 & 8 & 15 & 20 & 24 & 3.4 & $P$ \\
\hline 5. & $\mathrm{~N}$ & & 7 & 1 & 14 & 23 & 35 & 4.0 & $P$ \\
\hline 6. & $P$ & & 58 & 15 & 2 & 3 & 2 & 4.6 & $P$ \\
\hline 7. & $\mathrm{~N}$ & & 8 & 9 & 18 & 22 & 23 & 3.5 & $\mathrm{P}$ \\
\hline 8. & $\mathrm{~N}$ & & 15 & 13 & 15 & 23 & 14 & 3.1 & $\mathrm{P}$ \\
\hline 9. & $\mathrm{~N}$ & & 6 & 10 & 14 & 23 & 27 & 3.7 & $\mathrm{P}$ \\
\hline 10. & $\mathrm{P}$ & & 43 & 24 & 5 & 5 & 3 & 4.2 & $P$ \\
\hline 11. & $\mathrm{P}$ & & 41 & 29 & 2 & 5 & 3 & 4.3 & $P$ \\
\hline 12. & $\mathrm{P}$ & & 50 & 18 & 5 & - & 7 & 4.3 & $P$ \\
\hline 13. & $\mathrm{~N}$ & & 3 & 7 & 14 & 24 & 32 & 3.8 & $P$ \\
\hline 14. & $\mathrm{~N}$ & & 1 & 2 & 13 & 13 & 57 & 4.2 & $P$ \\
\hline 15. & $\mathrm{~N}$ & & 11 & 3 & 10 & 23 & 33 & 3.8 & $P$ \\
\hline 16. & $\mathrm{~N}$ & & 6 & 8 & 9 & 27 & 30 & 3.8 & $P$ \\
\hline 17. & $\mathrm{P}$ & & $\begin{array}{l}59 \\
\end{array}$ & 16 & 5 & - & - & 4.7 & $P$ \\
\hline 18. & $\mathrm{~N}$ & & 2 & 5 & 21 & 22 & 30 & 3.9 & $\mathrm{P}$ \\
\hline 19. & $\mathrm{P}$ & & 31 & 26 & 11 & 8 & 4 & 3.9 & $\mathrm{P}$ \\
\hline 20. & $\mathrm{~N}$ & & 11 & 9 & 18 & 20 & 22 & 3.4 & $\mathrm{P}$ \\
\hline \multicolumn{10}{|c|}{ Overall mean $\quad 4.912$} \\
\hline \multicolumn{2}{|c|}{ Variance } & 0.175 & & & & & & & \\
\hline \multicolumn{2}{|c|}{ Standard deviation } & 0.418 & & & & & & & \\
\hline \multicolumn{2}{|c|}{ Negative } & 2.4 an & elow & & & & & & \\
\hline \multicolumn{2}{|c|}{ Positive } & 2.5 an & oove & & & & & & \\
\hline
\end{tabular}


Table 7. Attitude of Students in Urban School (120)

\begin{tabular}{|c|c|c|c|c|c|c|c|c|c|}
\hline No & \multicolumn{2}{|c|}{$\begin{array}{l}\text { Attitude of } \\
\text { Students }\end{array}$} & SA & $\mathbf{A}$ & $\mathbf{U}$ & D & SD & $\begin{array}{l}\text { Mean } \\
\text { Scores }\end{array}$ & $\begin{array}{c}\text { Attitude of } \\
\text { Respondents }\end{array}$ \\
\hline 1 & \multicolumn{2}{|c|}{$\mathrm{N}$} & 29 & 17 & 7 & 23 & 44 & 3.3 & $P$ \\
\hline 2 & \multicolumn{2}{|l|}{$\mathrm{N}$} & 12 & 9 & 19 & 34 & 46 & 3.8 & $\mathrm{P}$ \\
\hline 3. & \multicolumn{2}{|l|}{$\mathrm{N}$} & 5 & 3 & 12 & 34 & 66 & 4.3 & $\mathrm{P}$ \\
\hline 4. & \multicolumn{2}{|l|}{$\mathrm{N}$} & 11 & 12 & 20 & 40 & 37 & 3.7 & $\mathrm{P}$ \\
\hline 5. & \multicolumn{2}{|l|}{$\mathrm{N}$} & 6 & 8 & 8 & 33 & 65 & 4.5 & $\mathrm{P}$ \\
\hline 6. & \multicolumn{2}{|l|}{$\mathrm{P}$} & 62 & 37 & 10 & 4 & 7 & 4.2 & $P$ \\
\hline 7. & \multicolumn{2}{|l|}{$\mathrm{N}$} & 16 & 14 & 25 & 48 & 17 & 3.3 & $\mathrm{P}$ \\
\hline 8. & \multicolumn{2}{|l|}{$\mathrm{N}$} & 16 & 16 & 32 & 33 & 23 & 3.3 & $\mathrm{P}$ \\
\hline 9. & \multicolumn{2}{|l|}{$\mathrm{N}$} & 12 & 6 & 21 & 54 & 27 & 3.7 & $\mathrm{P}$ \\
\hline 10. & \multicolumn{2}{|l|}{$\mathrm{P}$} & 38 & 46 & 13 & 16 & 7 & 3.8 & $\mathrm{P}$ \\
\hline 11. & \multicolumn{2}{|l|}{$\mathrm{P}$} & 46 & 46 & 18 & 4 & 6 & 4.0 & $\mathrm{P}$ \\
\hline 12. & \multicolumn{2}{|l|}{$\mathrm{P}$} & 65 & 39 & 10 & 4 & 2 & 4.3 & $P$ \\
\hline 13. & \multicolumn{2}{|l|}{$\mathrm{N}$} & 6 & 17 & 17 & 38 & 45 & 3.9 & $\mathrm{P}$ \\
\hline 14. & \multicolumn{2}{|l|}{$\mathrm{N}$} & 4 & 5 & 6 & 30 & 75 & 4.4 & $\mathrm{P}$ \\
\hline 15. & \multicolumn{2}{|l|}{$\mathrm{N}$} & 6 & 2 & 4 & 34 & 74 & 4.4 & $\mathrm{P}$ \\
\hline 16. & \multicolumn{2}{|l|}{$\mathrm{N}$} & 11 & 11 & 11 & 54 & 33 & 3.9 & $\mathrm{P}$ \\
\hline 17. & \multicolumn{2}{|l|}{$\mathrm{P}$} & 81 & 35 & 1 & 2 & 1 & 4.7 & $\mathrm{P}$ \\
\hline 18. & \multicolumn{2}{|l|}{$\mathrm{N}$} & 5 & 10 & 19 & 45 & 41 & 3.9 & $\mathrm{P}$ \\
\hline 19. & \multicolumn{2}{|l|}{$\mathrm{P}$} & 40 & 37 & 9 & 13 & 21 & 3.5 & $\mathrm{P}$ \\
\hline 20. & \multicolumn{2}{|l|}{$\mathrm{N}$} & 16 & 11 & 29 & 38 & 26 & 3.4 & $\mathrm{P}$ \\
\hline \multicolumn{10}{|c|}{ Overall mean 3.904} \\
\hline \multicolumn{2}{|c|}{ Variance } & 0.159 & & & & & & & \\
\hline \multicolumn{2}{|c|}{ Standard deviation } & 0.399 & & & & & & & \\
\hline \multicolumn{2}{|c|}{ Negative } & 2.4 an & elow & & & & & & \\
\hline \multicolumn{2}{|c|}{ Positive } & $2.5 \mathrm{an}$ & bove & & & & & & \\
\hline
\end{tabular}

Table 8. Comparison of the Mean View of Male and Female Students

\begin{tabular}{|l|l|l|l|l|l|l|l|}
\hline \multicolumn{1}{|c|}{ Gender } & \multicolumn{1}{|c|}{$\mathbf{N}$} & $\mathbf{X}$ & \multicolumn{1}{c|}{ SD } & \multicolumn{1}{c|}{ DF } & T & T. Tab & Rk \\
\hline Male & 100 & 4.008 & 0.371 & 198 & 2.02 & 1.96 & Sig. \\
\hline Female & 100 & 3.912 & 0.444 & & & & \\
\hline
\end{tabular}

Table 9. Comparision of Rural and Urban Location

\begin{tabular}{|l|l|l|l|l|l|l|l|}
\hline \multicolumn{1}{|c|}{ Location } & \multicolumn{1}{c|}{$\mathbf{N}$} & \multicolumn{1}{c|}{$\mathbf{X}$} & \multicolumn{1}{c|}{ SD } & DF & T & T. Tab & \multicolumn{1}{c|}{ Rm } \\
\hline Rural & 80 & 3.912 & 0.418 & 198 & 0.16 & 1.96 & Ns \\
\hline Urban & 120 & 3.904 & 0.399 & & & & \\
\hline
\end{tabular}

Table 10. Correlation of Students Attitude and Their Performance

\begin{tabular}{|l|l|l|l|l|l|l|l|}
\hline $\begin{array}{c}\text { Students' } \\
\text { Performance }\end{array}$ & \multicolumn{1}{|c|}{$\mathbf{N}$} & $\mathbf{X}$ & \multicolumn{1}{|c|}{ SD } & DF & T & T. Tab & Rm \\
\hline Attitude & 100 & 3.920 & 0.382 & 198 & 0.001 & 0.164 & Ns \\
\hline Performance & 100 & 47.26 & 5.74 & & & & \\
\hline
\end{tabular}

Table 11. Relationship between Attitude and Performance Levels of Students

\begin{tabular}{|l|l|l|l|l|l|l|l|}
\hline $\begin{array}{c}\text { School } \\
\text { Composition }\end{array}$ & \multicolumn{1}{|c|}{$\mathbf{N}$} & \multicolumn{1}{|c|}{$\mathbf{X}$} & \multicolumn{1}{|c|}{ SD } & \multicolumn{1}{|c|}{ DF } & T & T. Tab & \multicolumn{1}{|c|}{ Rm } \\
\hline Unisex & 8 & 3.850 & 0.416 & 198 & -1.48 & -1.96 & Sig. \\
\hline Mixed & 120 & 3.929 & 0.443 & & & & \\
\hline
\end{tabular}

